Как видим, мальчик мало употребляет в своей речи имена персонажей прочитанных книг. Только один раз он вспоминает о Робинзоне и то только в связи с ролевой игрой.

Таким образом, мотивационный уровень в структуре языковой личности Николеньки Иртеньева включает в себя речевые интенции, являющиеся главной составляющей общения, и систему прецедентных текстов, значимых для главного героя в познавательном и эмоциональном отношениях.

$$
* * *
$$

1. Караулов Ю.Н. Русский язык и языковая личность. - М.: Изд-во ЛКИ, 2010. - 264 с.

2. Красных В.В. Виртуальная реальности или реальная виртуальность? Человек. Сознание. Коммуникация. - М.: Диалог-МГУ, 1998. - 352 с.

3. Кузьмина Г.Ш. Синергетика концептосферы С.Т. Аксакова как русской языковой личности в дилогии «Семейная хроника» и «Детские годы Багрова - внука»: АКД. - Уфа, 2005. -17 с.

4. Толстой Л.Н. Детство. Отрочество. Юность. - Орджоникидзе: Ир, 1976. - 349 с.

\title{
Молчанова С.E. \\ Стилистический потенциал артиклей в художественном стиле современного английского языка
}

РФ ФГБОУВО «Российский государственный университет правосудия» (Россия, Ростов-на-Дону)

doi: 10.18411/sr-10-06-2021-68

Отступление от норм употребления артиклей в художественном стиле современного английского языка может носить ярко выраженный экспрессивный характер. Артикли способны также выполнять прагматическую, детализирующую и эмоциональную функции.

Употребление неопределенного артикля перед словами, обозначающими цвет, выражает некоторую степень неуверенности говорящего по поводу оттенка того или иного цвета, либо способствует большей детализации и конкретизации описания. Например: She was tall and slender, with eyes that were a startling dark brown in her pale face [3, p. 2]. Подобный оттенок подчёркивает необычную внешность одной из главных героинь.

Неопределенный артикль перед абстрактными существительными, обозначающими эмоции, человеческие качества и чувства, выражает некоторый аспект их проявления. Например: Honey spoke very little. There's a shyness about her, Paige thought. She's vulnerable. Some man probably broke her heart [3, p. 36]. С точки зрения говорящего стеснительность как черта характера в общем смысле девушке не свойственна, ей присуще лишь некоторое ее проявление в ситуациях, напоминающих о неприятных переживаниях в прошлом.

Повтор неопределенного артикля перед прилагательными, определяющими одно и то же существительное, подчеркивает важность каждого определения с точки зрения говорящего. Например: The Vicar is, in my judgment, both an amiable and a devoted man, who has served parish to the best of his ability [1, p. 372].

Неопределенный артикль перед существительным, обозначающим сильные эмоции, может эксплицировать презрительное отношение говорящего к проявлению подобного рода эмоций. Например: Anson disliked this sort of question ... There was a passion for delving into the mind of the criminal [1, p. 125].

Употребление неопределенного артикля в классифицирующем значении в конструкциях с повтором и параллельной структурой может передавать негодование и обиду героя. Например: He found himself resenting the fact that a squalid canalside murder was a TRAGEDY, and a miserable suicide was also a TRAGEDY. Whereas his own case had 
remained, from the beginning, an OUTRAGE [1, p. 178]. В данном примере достижению указанного эффекта способствуют также графические средства.

Повтор неопределенного артикля может подчеркивать разнообразие и несовместимость социальных ролей, которые приходится играть герою произведения. Например: As a son and a prisoner, George could not help being moved to tears by these words; as a lawyer, he doubted how much effect they would have on whichever Home Office functionary might eventually be appointed to review the case [1, p. 213]. Одновременное выполнение данных функций обусловливает противоречивый характер воздействия слов отца на героя, а также раскрывает причину его напряженного эмоционального состояния.

Употребление неопределенного артикля в номинативном значении при аргументации придает ей максимально объективный характер. Например: What I am asking is this. You believe that a respectable young solicitor, having shown no previous sign of a violent nature, suddenly goes out one night and attacks a pit pony in a most wicked and violent fashion [1, p. 382]. В примере речь идет о конкретном человеке и о конкретном животном, говорящий же употребляет неопределенный артикль для придания аргументам большей убедительности.

Неопределенный артикль, указывающий на то, что существительное является типичным представителем класса, в рассуждениях может свидетельствовать о традиционных взглядах героя. Например: A wedding means bridesmaids, but this has long been settled ... But a wedding also means a church, and a church means religion [1, p. 360]. Неопределенный артикль в сочетании со стилистическим приемом подхвата в данном примере придает рассуждению также логический характер.

Употребление неопределенного артикля перед существительным, являющимся единственным в своем роде, может передавать сомнение говорящего в существовании данного явления или смутное представление о нём. Например: She presumes that after she dies she will go to a Heaven whose exact nature she cannot describe, and remain there in a condition she cannot imagine [1, p. 266].

Частое употребление существительных с неопределенным артиклем в повествовании может создавать атмосферу неизвестности. Например: They set off across the field behind the Vicarage, climbed a fence, forced their way through a hedge, crossed the railway by a subterranean passage, climbed another fence, crossed another field, braved $\underline{a}$ clinging, thorny hedge, crossed another paddock, and found themselves on the edge of the Colliery field [1, p. 324]. Осуществляя расследование и исследуя путь, по которому должен был пройти преступник, герои сталкиваются с многочисленными препятствиями.

Использование неопределенного артикля с названиями комнат в доме героя может свидетельствовать о необычной для него атмосфере в этих комнатах. Например: I picked up my way across a living room full of little girls trying to move like Kylie Minogue in her latest video [2, p. 36]. Речь идет о гостиной главного героя, в которой отмечался день рождения его дочери.

Напротив, частое употребление определенного артикля в повествовании создает атмосферу до боли знакомой обстановки, способной вызывать те или иные эмоции, связанные с воспоминаниями событий, происходивших в ней. Например: Ten years ago he had chosen this room for her (his now dead wife) as having the best view, down into the garden and the private narrowing valley where the woods converged. ... He continued looking out of the bedroom window, down past the neglected ground to the valley. [1, p. 246]. Вид из комнаты его покойной жены вызывает у героя печаль и усугубляет чувство утраты.

Определенный артикль с существительными с разнородными значениями может способствовать передаче эффекта иронии. Например: Blanch Anson could sense male restiveness farther down the table. They were eager for the curtained study, the poked fire, the 
lit cigar, the glass of brandy, and the opportunity, in as civilized way as possible, to tear great lumps out of one another. She rose, and bade the combatants goodnight [1, p. 370].

Определенный артикль при повторе существительного помогает передать негодование и возмущение героя. Например: How easily everyone understood what was real and what was not. The world in which a benighted young solicitor was sentenced to penal servitude ... the world in which Holmes unraveled another mystery ... or the world beyond, the world behind the closed door, through which Touie had effortlessly slipped [1, p. 372].

Употребление субстантивированных прилагательных, выражающих абстрактные понятия, с определенным артиклем делает эти понятия более конкретными, реальными и доступными с точки зрения говорящего. Например: The invisible and the impalpable, which lie just below the surface of the real ... are increasingly being made visible and palpable [1, p. 277].

При перечислении в описании существительных, характеризующих эмоциональное состояние героя, употребление определенного артикля выделяет каждый аспект этого состояния, подчеркивая его постоянный характер. Например: But beneath the exhaustion, the anger and the fear, George discovered another emotion: relief [1, p. 148]. Контрастное появление в данном примере названия эмоции без артикля подчеркивает ее новизну.

При употреблении членом одной семьи определенного артикля перед существительным, обозначающим близкого родственника, выражается отношение восхищения и уважения к нему. Например: Only the Mam can confirm that the course of action he proposes is correct [1, p. 234]. Герой полностью доверяет своей матери и считает ее мнение истиной в последней инстанции.

Определенный артикль перед вопросительными местоимениями подчеркивает глубину и сложность вопросов, о которых идет речь. Например: Frankly, Campbell, the why interests me less than the how and the when and the what [1, p. 125]. Артикли свидетельствуют об обеспокоенности говорящего именно этим делом, о попытке выделить в нем основные аспекты расследования. Данный эффект подчеркивается также употреблением многосоюзия.

Переход от употребления определенного артикля, указывающего на то, что существительное обозначает класс как целое, к употреблению неопределенного артикля, характеризующего существительное как типичного представителя класса, противопоставляет эти существительные, а также создает эффект обманутого ожидания. Например: Most crimes ... occur without witnesses. The burglar waits for the house to be empty. The murderer waits until his victim is alone. The man who slashes the horse waits for the cover of night. If there is a witness, it is often an accomplice, another criminal. You catch a criminal, he lies [1, p. 381]. Параллельные конструкции подчеркивают, что все существительные представляют собой наименования преступников и их жертв.

Нулевой артикль придает существительным высокую степень абстракции. Например: Dubbs gave him a gentle shove, and he climbed up towards light and noise. As he emerged into the view of Court B, noise became silence. George stood self-consciously in the dock, an actor propelled unwillingly on stage through a trapdoor [1, p. 167]. Герой не осознает, что происходит вокруг, различает сигналы, но не ассоциирует их с источниками, словно все происходит не с ним.

Отсутствие артикля с приложениями может свидетельствовать о презрительном отношении говорящего к роду деятельности человека, о котором идет речь. Например: The morning of the second day began with the testimony of Joseph Markew, innkeeper and former police constable [1, p. 174]. Настолько разные виды деятельности, что возникает сомнение в компетентности данного героя. 
Нулевой артикль в сочетаниях, содержащих конкретные существительные, связанные союзом and, придает им абстрактный и обобщенный характер, а также подчеркивает восприятие говорящим этих объектов или явлений как единое целое. Например: I imagined driving up to Staffordshire with you at my side, the two of us, like man and wife [1, p. 309]. Часто размытость образов помогает читателю почувствовать их нереальность с точки зрения говорящего.

Артикли могут играть важную роль при создании некоторых стилистических приемов:

Неопределенный артикль при создании литоты привносит дополнительный смягчающий характер утверждению. Например: And if so, then only the police are lying ... A not impossible occurrence [1, p. 321].

Именно употребление определенного артикля способствует образованию стилистического приема антономазии. Например: Approaching her were Rhino and the Shadow [3, p. 262].

Неопределенный артикль свидетельствует о том, что словосочетание с предлогом of представляет собой инвертированный эпитет. Например: Wood had little trouble with long jennies; though he still had a devil of a distance to go with his doublebaulks [1, p. 344].

Различные стилистические эффекты могут создаваться при помощи неопределенного, определенного и нулевого артиклей, а также их чередования. Во многих случаях высокая степень экспрессивности достигается при сопровождении стилистического употребления артиклей таким стилистическим приемом как повтор. Артикли могут играть существенную роль при создании некоторых стилистических приемов.

$$
* * *
$$

1. Barnes J. Arthur and George. London: Vintage Books, 2006. 450 p.

2. Parsons T. Man and Wife. London: Harper, 2003. 297 p.

3. Sheldon S. Nothing Lasts Forever. New York: Grand Central Publishing, 1994. 384 p. 